\title{
Long-term effects of consumption of full-fat or reduced-fat products in healthy non-obese volunteers: assessment of energy expenditure and substrate oxidation.
}

Citation for published version (APA):

van Verboeket, W. P. H. G., Westerterp, K. R., Hermans-Limpens, T. J. F. M. B., de Graaf, C., van het Hof, K. H., \& Weststrate, J. A. (1996). Long-term effects of consumption of full-fat or reduced-fat products in healthy non-obese volunteers: assessment of energy expenditure and substrate oxidation. MetabolismClinical and Experimental, 45, 1004-1010. https://doi.org/10.1016/S0026-0495(96)90271-1

Document status and date:

Published: 01/01/1996

DOI:

10.1016/S0026-0495(96)90271-1

Document Version:

Publisher's PDF, also known as Version of record

Document license:

Taverne

Please check the document version of this publication:

- A submitted manuscript is the version of the article upon submission and before peer-review. There can be important differences between the submitted version and the official published version of record. People interested in the research are advised to contact the author for the final version of the publication, or visit the DOI to the publisher's website.

- The final author version and the galley proof are versions of the publication after peer review.

- The final published version features the final layout of the paper including the volume, issue and page numbers.

Link to publication

\footnotetext{
General rights rights.

- You may freely distribute the URL identifying the publication in the public portal. please follow below link for the End User Agreement:

www.umlib.nl/taverne-license

Take down policy

If you believe that this document breaches copyright please contact us at:

repository@maastrichtuniversity.nl

providing details and we will investigate your claim.
}

Copyright and moral rights for the publications made accessible in the public portal are retained by the authors and/or other copyright owners and it is a condition of accessing publications that users recognise and abide by the legal requirements associated with these

- Users may download and print one copy of any publication from the public portal for the purpose of private study or research.

- You may not further distribute the material or use it for any profit-making activity or commercial gain

If the publication is distributed under the terms of Article 25fa of the Dutch Copyright Act, indicated by the "Taverne" license above,

Download date: 26 Apr. 2023 


\title{
Long-Term Effects of Consumption of Full-Fat or Reduced-Fat Products in Healthy Non-obese Volunteers: Assessment of Energy Expenditure and Substrate Oxidation
}

\author{
Wilhelmine P.H.G. Verboeket-van de Venne, Klaas R. Westerterp, Tanja J.F.M.B. Hermans-Limpens, Cees de Graaf, \\ Karin H. van het Hof, and Jan A. Weststrate
}

\begin{abstract}
A study was performed to evaluate long-term (6-month) effects of consumption of full-fat products or reduced-fat products on energy and substrate metabolism. Subjects (age, 19 to 35 years; body mass index [BMI], 21 to $28 \mathrm{~kg} \cdot \mathrm{m}^{-2}$ ) were studied during a 36-hour stay in a respiration chamber, before (16 men) and in the third month (16 men) and sixth month (19 men and 17 women) of the study. The diet intervention caused, on average, a change in fat intake of (mean $\pm \mathrm{SE})+23 \pm 31 \mathrm{~g} / \mathrm{d}(P<.001)$ in the full-fat group and of $-5 \pm 29 \mathrm{~g} / \mathrm{d}(P<.05)$ in the reduced-fat group. Twenty-four-hour energy expenditure (EE), sleeping metabolic rate (SMR), diet-induced thermogenesis (DIT), and EE for physical activity (ACT) were not different between the groups. Fat oxidation was significantly $(P<.05)$ increased in the full-fat group and was not different from fat intake. During the 6 months of the study, body mass and fat mass were significantly increased in subjects of the full-fat group, whereas there were no changes in body mass or body composition in subjects of the reduced-fat group. It is concluded that in the long run, avoidance of a diet with full-fat products will promote body weight and fat stability.

Copyright 1996 by W.B. Saunders Company
\end{abstract}

W

EIGHT MAINTENANCE requires not only energy balance, but also balance between intake and oxidation of the three energy substrates: carbohydrate, protein, and fat. ${ }^{1,2}$ In situations of energy or substrate imbalance, changes occur in the body stores and hence body weight or body composition. A high-fat intake is often associated with an increasing prevalence of obesity. ${ }^{3-5}$ Possible mechanisms for this association are based on a positive energy balance (energy intake $[\mathrm{EI}]>$ energy expenditure $[\mathrm{EE}]$ ) or the failure to adjust fat oxidation to fat intake. One of the hypotheses to be tested is whether consumption of reducedfat products over a period of 6 months will lead to an increase of 24-hour EE. Changing the macronutrient ratio of the diet may have consequences for the regulation of energy balance through changes in one or more of the three components of daily EE: sleeping metabolic rate (SMR), diet-induced thermogenesis (DIT), and EE for physical activity (ACT).

Regardless of whether a change in 24-hour EE and its components is observed, diet composition can also affect substrate balance. Hill et al $^{6}$ studied short-term (7-day) effects of alterations in diet composition on EE and substrate balance. They reported that a rapidly shifting substrate oxidation more closely reflected the composition of the diet, without producing measurable effects on total EE. Furthermore, they predicted that continued consumption of a high-fat diet would not cause any major shift in either body energy or body composition, whereas prolonged consumption of a low-fat diet would lead to a period of negative fat balance and hence body energy loss.

From the Department of Human Biology, University of Limburg, Maastricht; Department of Human Nutrition, Wageningen Agricultural University, Wageningen; and Unilever Research Laboratorium, Vlaardingen, The Netherlands.

Submitted October 17, 1995; accepted January 17, 1996.

Address reprint requests to Wilhelmine P.H.G. Verboeket-van de Venne, PhD, Department of Human Biology, University of Limburg, PO Box 616, 6200 MD Maastricht, The Netherlands.

Copyright 1996 by W.B. Saunders Company

0026-0495/96/4508-0016\$03.00/0
The present study focused on long-term effects of consumption of full-fat or reduced-fat products on $\mathrm{EE}$ and substrate oxidation. It was part of a 6-month multicenter parallel comparison trial on long-term health effects of a realistic consumption of reduced-fat products by healthy non-obese individuals. In short, each of three participating centers recruited approximately 80 healthy volunteers $(20$ men and 20 women aged 19 to 35 years with BMI of 21 to 28 $\mathrm{kg} \cdot \mathrm{m}^{-2}$ and $20 \mathrm{men}$ and 20 women aged 36 to 55 years with BMI of 24 to $30 \mathrm{~kg} \cdot \mathrm{m}^{-2}$ ). Volunteers were randomized into two study groups (full-fat group and reduced-fat group), ensuring an equal distribution of both sexes, eating behavior characteristics, and type of household, as far as possible. Both groups were matched for mean age and body mass index (BMI). During a period of 6 months, subjects had free access to either full-fat products or reduced-fat products.

\section{SUBJECTS AND METHODS}

\section{Subjects}

The study was performed in men $(n=19)$ and women $(n=17)$ aged 19 to 35 years: 10 men and nine women in the full-fat group and nine men and eight women in the reduced-fat group. Their physical characteristics are presented in Table 1 . There were no significant differences between the full-fat and reduced-fat groups with respect to age, height, weight, or percentage body fat. The procedures used in the study were carefully explained to the subjects before they gave their consent to participate. The research protocol was reviewed and approved by the local ethics committee.

\section{Experimental Design}

EI and macronutrient intake in free-living conditions were determined by means of a 3-day dietary record at four different times. To determine the habitual EI of the subjects, the first measurement was performed before they entered the study (baseline measurement). The second, third, and fourth measurements occurred in the first, third, to fourth, and sixth month of the study.

EE and substrate oxidation were measured three times using a respiration chamber. The first measurement (baseline) and the second measurement (in the third month) of the study were performed in 16 men (eight full-fat group and eight reduced-fat 
Table 1. Physical Characteristics of the Subjects (mean \pm SD)

\begin{tabular}{lrllll}
\hline \multicolumn{1}{c}{ Group } & No. & Age $(\mathrm{yr})$ & Height $(\mathrm{m})$ & Weight $(\mathrm{kg})$ & Body Fat $(\%)$ \\
\hline Full-fat & & & & & \\
$\quad$ Men & 10 & $29 \pm 5$ & $1.82 \pm 0.05$ & $82.0 \pm 12.2$ & $22.4 \pm 6.9$ \\
$\quad$ Women & 9 & $27 \pm 6$ & $1.67 \pm 0.07$ & $67.4 \pm 6.9$ & $33.6 \pm 5.8$ \\
$\quad$ Total & 19 & $28 \pm 5$ & $1.75 \pm 0.10$ & $75.1 \pm 12.3$ & $27.7 \pm 8.5$ \\
Reduced-fat & & & & & \\
$\quad$ Men & 9 & $26 \pm 6$ & $1.80 \pm 0.04$ & $76.5 \pm 6.1$ & $20.1 \pm 7.2$ \\
$\quad$ Women & 8 & $24 \pm 4$ & $1.67 \pm 0.06$ & $62.1 \pm 4.1$ & $30.1 \pm 3.7$ \\
$\quad$ Total & 17 & $25 \pm 5$ & $1.73 \pm 0.08$ & $69.7 \pm 9.0$ & $24.8 \pm 7.7$ \\
Total & 36 & $27 \pm 5$ & $1.74 \pm 0.09$ & $72.6 \pm 11.1$ & $26.3 \pm 8.1$ \\
\hline
\end{tabular}

group). The third measurement was made in the sixth month of the study in all subjects (19 full-fat group and 17 reduced-fat group).

\section{Dietary Records}

Subjects recorded their food intake during 3 consecutive days ( 2 weekdays and 1 weekend day) in a diary that was divided into six periods per day (three meals and three intermeal periods). Brand names were elicited, as well as recipes that were used. Energy and macronutrient intake were calculated using the Dutch food composition table. ${ }^{7}$

\section{Respiration Chamber Measurements}

Subjects spent approximately 36 hours (from 7 PM on day 0 to 8 AM on day 2) in a respiration chamber, ${ }^{8}$ where $\mathrm{O}_{2}$ consumption and $\mathrm{CO}_{2}$ production were the main measurements. The $14-\mathrm{m}^{3}$ chamber was furnished with a bed, chair, table, television, radio, telephone, wash bowl, and toilet facilities and ventilated with fresh air at a rate of $50 \mathrm{~L} / \mathrm{min}$. The ventilation rate was measured with a dry gas meter (Schlumberg, type G6; Meterfabrick-Schlumberger, Dordrecht, The Netherlands). The concentration of $\mathrm{O}_{2}$ and $\mathrm{CO}_{2}$ was measured using a paramagnetic $\mathrm{O}_{2}$ analyzer (Servomex, type $\mathrm{OA}$ 184; Servomex, Crowborough, Sussex, UK) and an infrared $\mathrm{CO}_{2}$ analyzer (type URAS 3G; Hartmann \& Braun; Aksiengersellschaft, Frankfurt, Germany). Ingoing air was analyzed once every 15 minutes, and outgoing air once every 5 minutes. The gas sample to be measured was selected by a computer that also stored and processed the data. Physical activity of the subjects was monitored by means of a radar system based on the Doppler principle. During daytime, subjects were allowed to move freely, sit, lie down, study, use the telephone, listen to the radio, and watch television; only sleeping and strenuous exercise were not allowed.

Subjects were fed according to estimated energy balance a diet with full-fat products or a diet with reduced-fat products. During the baseline measurement, all subjects received a full-fat diet. EI for the maintenance of energy balance was based on the subjects' calculated basal metabolic rate ${ }^{9}$ multiplied by $1.4 .^{10}$ The diets were consumed as four meals daily: a breakfast at 8 AM containing $20 \%$ of the daily EI ( 20 energy \%), a lunch at 12:30 PM (25 energy \%), a dinner at 5:30 PM (45 energy \%), and an evening snack at 7:30 PM (10 energy \%). The full-fat diet provided 45 energy \% carbohydrate, 15 energy $\%$ protein, and 40 energy $\%$ fat. The reduced-fat diet was actually based on the full-fat diet, in which the full-fat products were isoenergetically replaced by reduced-fat equivalents. For example, subject A consumes a full-fat diet of $10.5 \mathrm{MJ} / \mathrm{d}$ containing $40 \mathrm{~g}$ full-fat cheese $(1,640 \mathrm{~kJ} / 100 \mathrm{~g}$; in total, $656 \mathrm{~kJ})$. Subject $B$ consuming a reduced-fat diet of $10.5 \mathrm{MJ} / \mathrm{d}$ then receives $52 \mathrm{~g}$ reduced-fat cheese $(1,254 \mathrm{~kJ} / 100 \mathrm{~g})$ to obtain to same energy content. Because fat was exchanged not only by carbohydrate but also by protein, the macronutrient composition of the reduced-fat diet was 54 energy $\%$ carbohydrate, 21 energy $\%$ protein, and 25 energy $\%$ fat.

$\mathrm{EE}$ and overall substrate oxidation were calculated from $\mathrm{O}_{2}$ consumption, $\mathrm{CO}_{2}$ production, and urinary nitrogen excretion, using the equations of Carpenter as described by Brouwer. ${ }^{11}$ Twenty-four-hour urine samples were collected from 7:30 AM to 7:30 AM. Samples were stored in containers with $10 \mathrm{~mL} \mathrm{H}_{2} \mathrm{So}_{4}$ to prevent ammonia loss through evaporation; volume and nitrogen concentration were measured subsequently, the latter with a Heraeus analyzer (type CHN-O-Rapid; W.C. Heraeus, Hanau, Germany). Twenty-four-hour EE and oxidation of carbohydrate, protein, and fat were calculated from 7:30 AM to 7:30 AM. SMR was determined by selecting a period of 3 consecutive hours between 2:00 and 7:00 AM, when EE was lowest and radar output was at baseline. DIT was calculated from the individual relationship between physical activity and EE both averaged over 30 minutes, as described previously. ${ }^{12}$ ACT was assessed by 24 -hour EE minus SMR minus DIT.

Body mass of the subjects was measured at the start and in the second, fourth, and sixth month of the study. Subjects were weighed (in underwear) in the morning upon rising, after voiding, and before any food or drink consumption, on a digital balance (Sauter, type E 1200; August Sauter, Albstadtl-Ebingen, Germany)

Table 2. EI, EE, and Energy Balance (EI - EE) Over 24 Hours During the Stay in the Respiration Chamber and El in Free-Living Conditions (EI dietary record) and Body Mass in Subjects of the Full-Fat Group $(n=8)$ and the Reduced-Fat Group $(n=8)$

\begin{tabular}{|c|c|c|c|c|c|}
\hline Group & Baseline & Third Month & Sixth Month & $\Delta$ Month 3-0 & $\Delta$ Month 6-0 \\
\hline \multicolumn{6}{|l|}{ Full-fat } \\
\hline 24-h El dietary record $(\mathrm{MJ} / \mathrm{d})$ & $11.0 \pm 1.3$ & $12.5 \pm 1.0$ & $10.8 \pm 1.2$ & $+1.4 \pm 1.2$ & $-0.2 \pm 1.1$ \\
\hline 24-h El (MJ/d) & $11.3 \pm 0.4$ & $11.3 \pm 0.3$ & $11.3 \pm 0.3$ & $0.0 \pm 0.0$ & $0.0 \pm 0.0$ \\
\hline 24-h EE (MJ/d) & $10.7 \pm 0.3$ & $11.2 \pm 0.4 \dagger$ & $11.2 \pm 0.4$ & $+0.6 \pm 0.1$ & $+0.5 \pm 0.2$ \\
\hline 24-h energy balance ( $\mathrm{MJ} / \mathrm{d}$ ) & $+0.7 \pm 0.2$ & $+0.1 \pm 0.2 \ddagger$ & $+0.2 \pm 0.2$ & $-0.6 \pm 0.2$ & $-0.5 \pm 0.2$ \\
\hline Body mass $(k g)$ & $85.0 \pm 4.2$ & & $87.8 \pm 3.7 \ddagger$ & & $+2.8 \pm 1.0$ \\
\hline \multicolumn{6}{|l|}{ Reduced-fat } \\
\hline 24-h El dietary record ( $\mathrm{MJ} / \mathrm{d})$ & $11.7 \pm 1.1$ & $12.0 \pm 0.8$ & $10.3 \pm 1.1$ & $+0.3 \pm 0.6$ & $-1.4 \pm 1.2$ \\
\hline 24-h El (MJ/d) & $10.8 \pm 0.1$ & $10.8 \pm 0.1$ & $10.6 \pm 0.2$ & $0.0 \pm 0.0$ & $-0.1 \pm 0.1$ \\
\hline 24-h EE (MJ/d) & $10.2 \pm 0.2$ & $10.6 \pm 0.2 \dagger$ & $10.7 \pm 0.2 \dagger$ & $+0.4 \pm 0.1$ & $+0.5 \pm 0.1$ \\
\hline 24-h energy balance (MJ/d) & $+0.6 \pm 0.2$ & $+0.2 \pm 0.2 \dagger$ & $0.0 \pm 0.3 \ddagger$ & $-0.4 \pm 0.1$ & $-0.7 \pm 0.2$ \\
\hline Body mass $(\mathrm{kg})$ & $76.0 \pm 2.2$ & & $75.6 \pm 2.3^{*}$ & & $-0.4 \pm 0.8^{*}$ \\
\hline
\end{tabular}

NOTE. Subjects of the reduced-fat group consumed a full-fat diet at the baseline measurement in the respiration chamber. El dietary record at baseline represents the habitual diet of the subjects before entering the study. Results are the mean $\pm \mathrm{SE}$.

$* P<.05$ for difference between groups.

$\dagger P<.01, \neq P<.05:$ differences from baseline value within groups. 
Table 3. SMR, DIT, and ACT Before and in the Third and Sixth Month of the Study in Subjects of the Full-Fat Group $(n=8)$ and the Reduced-Fat Group ( $n=8$ )

\begin{tabular}{llllll}
\hline Group & Baseline & Third Month Sixth Month & $\Delta$ Month $3-0$ & $\Delta$ Month 6-0 \\
\hline Full-fat & & & & \\
$\quad$ SMR & $7.8 \pm 0.3$ & $8.3 \pm 0.4 \dagger$ & $8.2 \pm 0.4 \dagger$ & $+0.5 \pm 0.2+0.4 \pm 0.2$ \\
DIT & $1.1 \pm 0.1$ & $1.1 \pm 0.1$ & $1.3 \pm 0.2$ & $0.0 \pm 0.1+0.3 \pm 0.1$ \\
ACT & $1.8 \pm 0.2$ & $1.9 \pm 0.1$ & $1.6 \pm 0.1$ & $0.0 \pm 0.2-0.2 \pm 0.2$ \\
Reduced-fat & & & & & \\
SMR & $7.4 \pm 0.1$ & $7.5 \pm 0.1$ & $7.6 \pm 0.1$ & $+0.1 \pm 0.1+0.2 \pm 0.2$ \\
DIT & $1.4 \pm 0.1$ & $1.6 \pm 0.1 *$ & $1.3 \pm 0.1$ & $+0.2 \pm 0.1-0.1 \pm 0.2$ \\
ACT & $1.4 \pm 0.1$ & $1.5 \pm 0.1$ & $1.7 \pm 0.2$ & $+0.1 \pm 0.1+0.4 \pm 0.2$ \\
\hline
\end{tabular}

NOTE. All data are expressed in $\mathrm{MJ} / \mathrm{d}$ and are the mean $\pm \mathrm{SE}$. Subjects of the reduced-fat group consumed a full-fat diet at the baseline measurement.

${ }^{*} P<.01$ for difference between groups.

$+P<.05$ for difference from baseline value within groups.

accurate to $0.001 \mathrm{~kg}$. Body composition was assessed at the start and in the sixth month of study, using the deuterium dilution technique. ${ }^{13}$ Before subjects went to bed at night, they drank a ${ }^{2} \mathrm{H}_{2} \mathrm{O}$ dilution after voiding (baseline urine sample). The standard dose was, on average, $3.69 \pm 0.15 \mathrm{~g}^{2} \mathrm{H}_{2} \mathrm{O}$ (mean $\pm \mathrm{SD}$ ), filled up with tap water to approximately $75 \mathrm{~g}$, resulting in an enrichment of $\pm 5 \%$. The ${ }^{2} \mathrm{H}$ excess created was $84 \pm 16 \mathrm{ppm}$. A second urine sample was collected by the subjects on the next day in the morning, from the second voiding between 8:00 and 10:00 AM.
Deuterium content was measured in urine samples with an isotope ratio mass spectrometer (VG Aqua Sira; Tsogas, Middlewich, Cheshire, UK). Total body water (TBW) was calculated as the deuterium dilution space divided by 1.04 , correcting for exchange of the deuterium label with nonaqueous hydrogen of body solids. ${ }^{14}$ Fat-free mass was calculated from TBW assuming a hydration coefficient of 0.73 ; fat mass was calculated as body mass minus fat-free mass.

\section{Analysis of Data}

Differences between subjects of the full-fat and reduced-fat groups (treatment effects) were tested using unpaired $t$ tests. The within-group effects due to prolonged consumption of experimental products (exposure effects) were analyzed by repeatedmeasures ANOVA and Scheffé $F$ tests. To correct for the values at baseline, we also calculated the change $(\Delta)$ over 3 or 6 months ( $\Delta$ month 3-0 and $\Delta$ month 6-0). These $\Delta$ values were furthermore obtained to assess whether an effect is already present after 3 months of the study, or only after 6 months. Correlations between physical activity and EE were analyzed using the Pearson correlation coefficient. The data are expressed as the mean $\pm \mathrm{SD}$ or SE.

\section{RESULTS}

\section{Diet Intervention}

Data on macronutrient intake in free-living conditions for all subjects completing the 6-month multicenter parallelcomparison trial (full-fat group, $\mathrm{n}=103$; reduced-fat group,
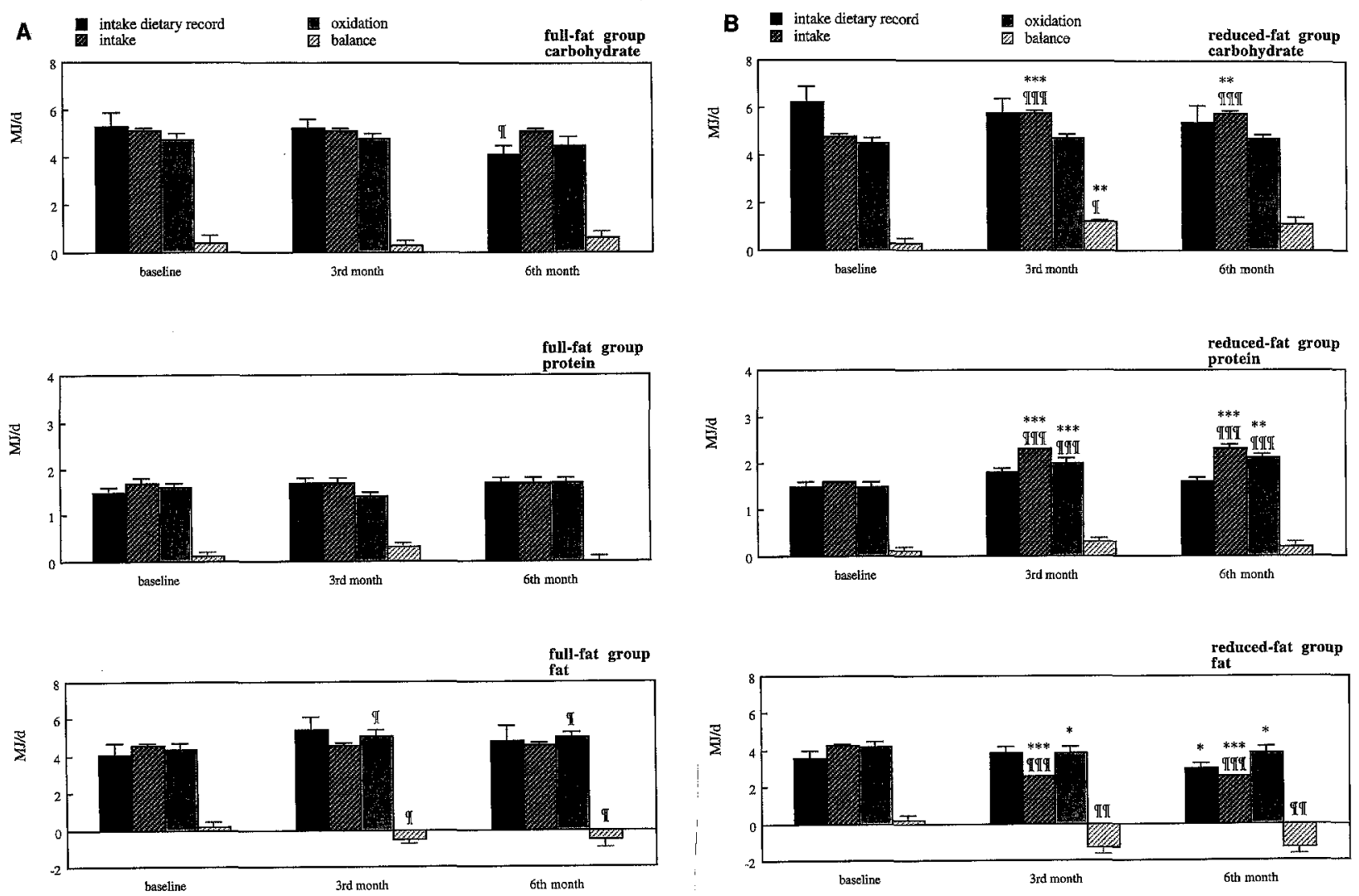

Fig 1. Mean intake, oxidation, and balance (intake - oxidation) of carbohydrate, protein, and fat over 24 hours during the stay in the respiration chamber in subjects of the full-fat group $(A, n=8)$ and reduced-fat group $(B, n=8)$. Substrate intake in free-living conditions, assessed by means of dietary records, is also presented. Data are expressed as the mean \pm SE. Note that subjects of the reduced-fat group consumed a full-fat diet at the baseline measurement in the respiration chamber. Substrate intake according to the dietary record at baseline represents habitual intake of the subjects before entering the study. ${ }^{* * * P}<.001, * * P<.01, * P<.05:$ differences between groups. ๆा $P<.001$, $\llbracket \uparrow P<.01, \uparrow P<.05$ : differences from baseline value within groups. 
$\mathrm{n}=117)$ showed that the diet intervention caused a change (mean $\pm \mathrm{SE})$ in fat intake of $+23 \pm 31 \mathrm{~g} / \mathrm{d}(P<.001)$ in the full-fat group and $-5 \pm 29 \mathrm{~g} / \mathrm{d}(P<.05)$ in the reduced-fat group (C. de Graaf, J.J.M.M. Drjvers, N.J.H. Zimmermans, et al, personal communication, August 1995). A similar tendency was observed in the subgroups subjected to measurements of $\mathrm{EE}$ and substrate oxidation: $+17 \pm 9$ $\mathrm{g} / \mathrm{d}$ in the full-fat group $(\mathrm{n}=19)$ and $-3 \pm 8 \mathrm{~g} / \mathrm{d}$ in the reduced-fat group $(\mathrm{n}=17)$.

\section{Energy Metabolism}

Treatment effects. Data on EI, EE, and energy balance (EI - EE) are presented in Table 2. There were no differences in these data between subjects in the full-fat and reduced-fat groups. The components SMR and ACT also were not different between the groups (Table 3 ). In the third month of the study, DIT was significantly higher in subjects of the reduced-fat group versus the full-fat group. However, at the end of the study, no effect of the type of diet on DIT was observed.

Exposure effects. In subjects of both the full-fat and reduced-fat groups, we observed a significantly increased 24-hour $\mathrm{EE}$ in the third month of the study as compared with the baseline measurement (Table 2). In the sixth month of the study, 24-hour EE was still elevated in both groups, but only significantly in the reduced-fat group. The change in 24-hour EE over 6 months ( $\Delta$ month 6-0) was the same for both groups. Subjects in the full-fat group did not show a persistent increase in 24-hour EE despite a significant weight gain, possibly because most of the gained weight represented fat (Table 5). In subjects of the full-fat group only, SMR was significantly increased in the third and sixth month of the study as compared with the baseline measurement (Table 3).

\section{Substrate Metabolism}

Treatment effects. In the third and sixth month of the study, carbohydrate and protein intake were significantly elevated at the expense of fat in subjects of the reduced-fat group as compared with the full-fat group (Figs 1 and 2). Oxidation of carbohydrate was not different between the groups, resulting in a more positive carbohydrate balance in subjects of the reduced-fat group (third month, $P<.01$; sixth month, $P>.05$ ). Because intake and oxidation of protein were equally elevated in subjects of the reduced-fat group, no difference in protein balance was observed between the groups. Fat intake and fat oxidation were significantly lower in subjects of the reduced-fat group as compared with the full-fat group. Consequently, fat balance was not different between the groups. Fat intake in free-
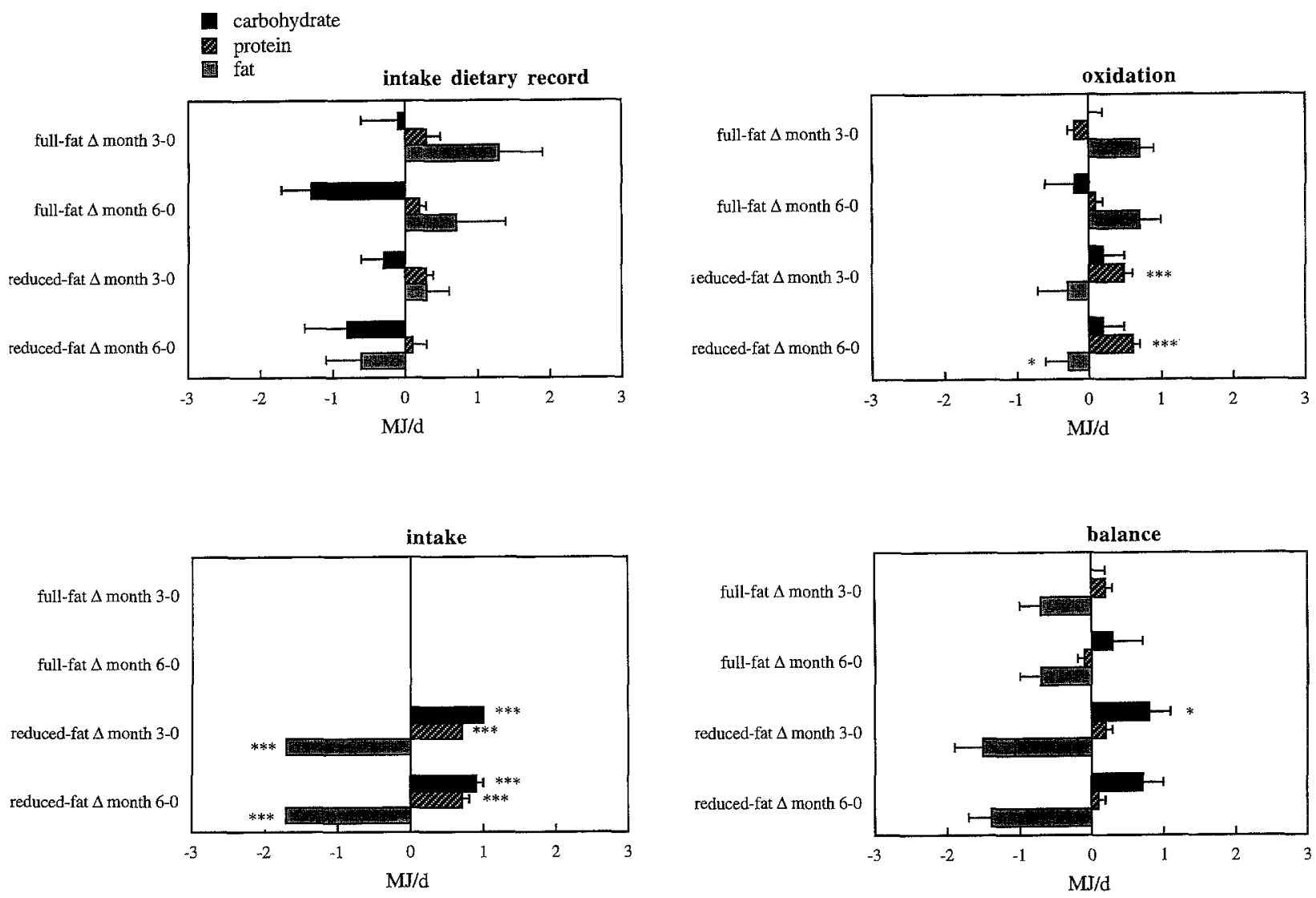

Fig 2. Changes in mean intake, oxidation, and balance (intake - oxidation) of carbohydrate, protein, and fat over 3 and 6 months ( $\Delta$ month $3-0$ and $\Delta$ month $6-0)$ in subjects of the full-fat group $(n=8)$ and reduced-fat group $(n=8)$. Changes in substrate intake in free-living conditions, assessed by means of dietary records, are also presented. Data are expressed as the mean \pm SE. Note that subjects of the reduced-fat group consumed a full-fat diet at the baseline measurement in the respiration chamber. Substrate intake according to the dietary record at baseline represents habitual intake of the subjects before entering the study. ${ }^{* *} P<.001, * P<.05:$ differences between groups. 
living conditions was only significantly lower in the sixth month of the study in subjects of the reduced-fat group as compared with the full-fat group.

In the sixth month of the study, additional subjects were studied (in total, 19 full-fat group and 17 reduced-fat group). In this larger group of subjects, the difference in fat oxidation between subjects of the full-fat and reduced-fat groups was highly significant, resulting in a more negative $(P<.05)$ fat balance in subjects of the reduced-fat group (Table 4).

Exposure effects. With respect to within-group effects, carbohydrate intake in free-living conditions was significantly decreased in the sixth month of the study in subjects of the full-fat group as compared with the baseline measurement (Fig 1). Furthermore, we observed a significantly increased fat oxidation in these subjects in the third and sixth month of the study, resulting in a negative fat balance $(P<.05)$. In the reduced-fat group, a significant difference in substrate intake was induced during the second (thirdmonth) and third (sixth-month) measurement in the respiration chamber as compared with the baseline measurement: carbohydrate and protein intake increased and fat intake decreased. The data on substrate oxidation during the study showed a significant increase in protein oxidation, whereas carbohydrate and fat oxidation remained at the same level as measured during the baseline measurement. Overall, carbohydrate balance was more positive in the third month $(P<.05)$ and sixth month $(P>.05)$, protein balance was unchanged, and fat balance became negative in the third and sixth month of the study $(P<.01)$.

\begin{tabular}{|c|c|c|}
\hline Parameter & Full-Fat & Reduced-Fat \\
\hline El dietary record & $10.1 \pm 0.7$ & $9.9 \pm 0.6$ \\
\hline $\mathrm{EI}$ & $9.9 \pm 0.3$ & $9.6 \pm 0.3$ \\
\hline $\mathrm{EE}$ & $10.1 \pm 0.3$ & $9.8 \pm 0.3$ \\
\hline Energy balance & $-0.2 \pm 0.2$ & $-0.2 \pm 0.2$ \\
\hline Carbohydrate intake dietary record & $4.1 \pm 0.3$ & $5.0 \pm 0.4$ \\
\hline Carbohydrate intake & $4.5 \pm 0.2$ & $5.2 \pm 0.2 \dagger$ \\
\hline Carbohydrate oxidation & $4.1 \pm 0.2$ & $4.4 \pm 0.2$ \\
\hline Carbohydrate balance & $+0.4 \pm 0.1$ & $+0.8 \pm 0.2$ \\
\hline Protein intake dietary record & $1.5 \pm 0.1$ & $1.5 \pm 0.1$ \\
\hline Protein intake & $1.5 \pm 0.1$ & $2.0 \pm 0.1^{*}$ \\
\hline Protein oxidation & $1.4 \pm 0.1$ & $1.8 \pm 0.1 \dagger$ \\
\hline Protein balance & $+0.1 \pm 0.0$ & $+0.2 \pm 0.1$ \\
\hline Fat intake dietary record & $4.3 \pm 0.4$ & $3.2 \pm 0.3 \mp$ \\
\hline Fat intake & $4.0 \pm 0.1$ & $2.3 \pm 0.1^{*}$ \\
\hline Fat oxidation & $4.6 \pm 0.2$ & $3.5 \pm 0.2^{*}$ \\
\hline Fat balance & $-0.6 \pm 0.2$ & $-1.2 \pm 0.2 \mp$ \\
\hline
\end{tabular}

NOTE. All data are expressed in MJ/d and are the mean \pm SE. Energy and substrate intake in free-living conditions, assessed by means of a dietary record, are also presented.

${ }^{*} P<.001, \dagger P<.01, \ddagger P<.05$ : differences between groups.

\section{Body Mass and Body Composition}

Treatment effects. The data on body mass and body composition of all subjects are presented in Table 5 . Concerning the absolute values of both groups of subjects, we only observed a significant difference in fat mass in the sixth month of the study. However, the relative values $(\Delta$ values) revealed more useful information because of the correction for baseline values. During the 6 months of the study, body mass, fat mass, and percent body fat were found to be significantly increased in subjects of the full-fat group versus the reduced-fat group.

Exposure effects. In subjects of the full-fat group, body mass significantly increased during the time of the study. The data on body composition showed that the weight gain was mainly in the form of fat:fat mass increased significantly during the study, whereas fat-free mass remained unchanged. In subjects of the reduced-fat group, no changes in body mass or body composition were observed.

\section{DISCUSSION}

It is generally accepted that a high fat intake is an important factor promoting obesity. Considering obesity as the result of a positive energy balance, there are two possible mechanisms for the association between fat intake and the development of obesity. A high-fat diet may cause an increase of EI or a decrease of EE. Several studies have described an increased EI in subjects consuming a high-fat diet for 2 days, ${ }^{15} 7$ days, ${ }^{16}$ and 14 days. ${ }^{17}$ In the long term (11 weeks), energy intake was found to be reduced on a low-fat diet ( 20 to 25 energy \% fat) compared with a control diet (35 to 40 energy \% fat), resulting in a significantly greater weight loss on a low-fat diet. ${ }^{18}$ Concerning the effect of diet composition on 24-hour EE, most studies failed to show a significant effect. ${ }^{6,16,19,20}$ SMR was found to be increased on a low-fat diet versus a mixed diet, ${ }^{19}$ or was not affected by diet composition. ${ }^{6,16,20}$ DIT was expected to be increased on a low-fat diet, because of the greater obligatory cost of glycogen storage and possibly because of a facultative increase in thermogenesis due to glucogenic stimulation of the sympathetic nervous system. ${ }^{21,22}$ However, a difference in DIT due to a changing diet composition was not observed. ${ }^{20}$ ACT also was not affected by diet composition. ${ }^{6,16,20}$ In the present study, the type of diet (full-fat or reduced-fat) had no remarkable effects on 24-hour EE or its components.

When comparing the diet consumed during the respiration chamber measurement with the macronutrient composition of the 3-day dietary record kept during free-living conditions, it is observed that during the respiration chamber measurement, subjects in the full-fat group received more carbohydrate (4 energy $\%, P<.05$ ) and less alcohol ( 2 energy $\%, P<.05$ ) and subjects in the reduced-fat group received more carbohydrate ( 5 energy $\%, P<.01$ ), more protein (6 energy $\%, P<.001)$, less fat (8 energy $\%$, $P<.001)$, and less alcohol $(2$ energy $\%, P<.01)$.

Considering the effects of diet composition on substrate oxidation and substrate balance, results of the present study were consistent with results of studies examining short-term effects of dietary fat and carbohydrate ${ }^{6,23}$ : (1) substrate 
Table 5. Body Mass and Body Composition During the Six-Month Experimental Period in Subjects of the Full-Fat Group (n = 19) and the Reduced-Fat Group $(\mathbf{n}=\mathbf{1 7})$

\begin{tabular}{|c|c|c|c|c|c|c|c|}
\hline Group & Baseline & Second Month & Fourth Month & Sixth Month & $\Delta$ Month 2-0 & $\Delta$ Month 4-0 & $\Delta$ Month 6-0 \\
\hline \multicolumn{8}{|l|}{ Full-fat } \\
\hline Body mass $(\mathrm{kg})$ & $75.1 \pm 2.8$ & $76.0 \pm 2.9 \dagger$ & $76.2 \pm 2.9$ & $77.0 \pm 2.9 \dagger$ & $+0.9 \pm 0.3$ & $+1.1 \pm 0.5$ & $+1.9 \pm 0.6$ \\
\hline Fat mass (kg) & $20.8 \pm 1.6$ & & & $22.3 \pm 1.7 \ddagger$ & & & $+1.5 \pm 0.6$ \\
\hline Fat-free mass $(\mathrm{kg})$ & $54.3 \pm 2.5$ & & & $54.8 \pm 2.5$ & & & $+0.5 \pm 0.4$ \\
\hline Body fat $(\%)$ & $27.7 \pm 2.0$ & & & $28.8 \pm 2.0$ & & & $+1.1 \pm 0.7$ \\
\hline \multicolumn{8}{|l|}{ Reduced-fat } \\
\hline Fat mass $(\mathrm{kg}\rangle$ & $17.1 \pm 1.3$ & & & $16.6 \pm 1.6^{*}$ & & & $-0.6 \pm 0.6^{*}$ \\
\hline Fat-free mass $(\mathrm{kg})$ & $52.6 \pm 2.3$ & & & $53.2 \pm 2.3$ & & & $+0.6 \pm 0.5$ \\
\hline Body fat $(\%)$ & $24.8 \pm 1.9$ & & & $23.8 \pm 2.1$ & & & $-1.0 \pm 0.7^{*}$ \\
\hline
\end{tabular}

NOTE. All subjects consumed their habitual diet at the baseline measurement.

${ }^{*} P<.05$ for difference between groups.

$\dagger P<.01, \neq P<.05$ : differences from baseline value within groups.

oxidation more closely corresponded to substrate intake on diets with a higher fat content, and (2) carbohydrate balance was (more) positive and fat balance (more) negative on low-fat diets. In the sixth month of the study, no significant effect of the type of diet was observed on carbohydrate and protein balances (Fig 1 and Table 4). However, fat balance was different between subjects of the full-fat and reduced-fat groups, ie, fat oxidation was greater than fat intake in subjects of the reduced-fat group, reaching significance $(P<.05)$ in the larger group of subjects (Table 4). The finding that subjects of both the full-fat and reduced-fat groups were in a negative fat balance during the respiration chamber measurement (Table 4) does not have consequences for the regulation of body weight. In fact, fat intake was higher in free-living conditions than in the respiration chamber (see above), especially in subjects of the reduced-fat group.

Sheppard et $\mathrm{al}^{24}$ examined weight changes in female subjects enrolled in a low-fat dietary intervention trial. Participants were randomly assigned to an intervention group that received intensive instruction in maintaining a low-fat diet or to a control group. After 1 year, subjects in the intervention group showed decreased fat intake from 39 to 22 energy \% and a decrease in weight of $3.1 \mathrm{~kg}$. Subjects in the control group showed decreased fat intake from 39 to 37 energy $\%$ and a decrease in weight of $0.4 \mathrm{~kg}$. They concluded that weight loss was more strongly associated with the change in percent energy from fat than with the change in total EI. In the present study, similar results were expected: the target of the design was to obtain a reduction in fat intake in the reduced-fat group from 40 energy $\%$ to
30 to 35 as compared with the full-fat group. However, data from the 6-month multicenter parallel-comparison trial indicated that the habitual fat intake was less than the expected 40 energy $\%$, resulting in a change in fat intake from 36 to 41 energy \% in the full-fat group and from 35 to 33 energy \% in the reduced-fat group (C. de Graaf, J.J.M.M. Drjvers, N.J.H. Zimmerman, et al, personal communication, August 1995). Combining these data with the results of the present study, it is suggested that subjects of the full-fat group increased their fat intake during the study, resulting in a significant increase of body mass and fat mass, whereas subjects in the reduced-fat group slightly decreased their fat intake, having no consequences for body mass or body composition. The change in fat mass in subjects of the full-fat group may explain the increased fat oxidation in this group, as noted by Schutz et al. 25

In summary, the results of this study showed no longterm effects of consumption of full-fat products or reducedfat products on 24-hour EE, SMR, DIT, and ACT. During the 6 months of the study, fat intake, body mass, and fat mass were, on average, significantly increased in subjects of the full-fat group, whereas fat intake showed a slight decrease with no consequences for body mass and fat mass in subjects of the reduced-fat group. It is concluded that in the long run, avoidance of a diet with full-fat products will promote body weight and fat stability.

\section{ACKNOWLEDGMENT}

We thank Nicole Wijckmans-Duysens, Janine Engels, and Marianne Bleumink for assistance during the respiration chamber measurements.

\section{REFERENCES}

1. Flatt JP: The difference in the storage capacities for carbohydrate and for fat, and its implications in the regulation of body weight. Ann NY Acad Sci 499:104-123, 1987

2. Flatt JP: Importance of nutrient balance in body weight regulation. Diabetes Metab Rev 6:571-581, 1988

3. Dreon DM, Frey-Hewitt B, Ellsworth N, et al: Dietary fat:carbohydrate ratio and obesity in middle-aged men. Am J Clin Nutr 47:995-1000, 1988

4. Romieu I, Willett WC, Stampfer MJ, et al: Energy intake and other determinants of relative weight. Am J Clin Nutr 47:406-412, 1988

5. Tremblay A, Plourde G, Despres JP, et al: Impact of dietary fat content and fat oxidation on energy intake in humans. Am J Clin Nutr 49:799-805, 1989

6. Hill JO, Peters JC, Reed GW, et al: Nutrient balance in humans: Effects of diet composition. Am J Clin Nutr 54:10-17, 1991

7. NEVO Tabel, Nederlands voedingsstoffen-bestand 1993. 
NEVO and Voorlichtingsbureau voor de Voeding, Den Haag, Nederlands, 1993

8. Schoffelen PFM, Saris WHM, Westerterp KR, et al: Evaluation of an automatic indirect calorimeter for measurement of energy balance in man. Eur Nutr Rep 5:51-54, 1984

9. Harris JA, Benedict FG: A Biometric Study of Basal Metabolism in Man. Washington, DC, Carnegie Institute, publication no. 279, 1919, pp 1-266

10. Verboeket-van de Venne WPHG: Pattern of Food Intake, Diet Composition and Human Energy Metabolism-An Experimental Approach. Maastricht, The Netherlands, Datawyse, 1993

11. Brouwer $E$ : On simple formulae for calculating the heat expenditure and the quantities of carbohydrate and fat oxidized in metabolism of men and animals, from gaseous exchange (oxygen intake and carbonic acid output) and urine-N, Acta Physiol Pharmacol Neerlandica 6:795-802, 1957

12. Verboeket-van de Venne WPHG, Westerterp KR, Kester ADM: Effect of the pattern of food intake on human energy metabolism. Br J Nutr 70:103-115, 1993

13. Van Marken Lichtenbelt WD, Westerterp KR, Wouters L: Deuterium dilution as a method to determine total body water: Effect of test protocol and sampling time. Br J Nutr 72:491-497, 1994

14. Schoeller DA, Van Santen E, Peterson DW, et al: Total body water measurement in humans with ${ }^{18} \mathrm{O}$ and ${ }^{2} \mathrm{H}$ labeled water. Am J Clin Nutr 33:2686-2693, 1980

15. Tremblay A, Lavallée $\mathrm{N}$, Alméras $\mathrm{N}$, et al: Nutritional determinants of the increase in energy intake associated with a high-fat diet. Am J Clin Nutr 53:1134-1137, 1991

16. Thomas CD, Peters JC, Reed GW, et al: Nutrient balance and energy expenditure during ad libitum feeding of high-fat and high-carbohydrate diets in humans. Am J Clin Nutr 55:934-942, 1992

17. Lissner L, Levitsky DA, Strupp BI, et al: Dietary fat and the regulation of energy intake in human subjects. Am J Clin Nutr $46: 886-892,1987$

18. Kendall A, Levitsky DA, Strupp BJ, et al: Weight loss on a low-fat diet: Consequence of the imprecision of the control of food intake in humans. Am J Clin Nutr 53:1124-1129, 1991

19. Hurni M, Burnand B, Pittet P, et al: Metabolic effects of a mixed and a high-carbohydrate low-fat diet in man, measured over $24 \mathrm{~h}$ in a respiration chamber. Br J Nutr 47:33-43, 1982

20. Abbott WGH, Howard BV, Ruotolo G, et al: Energy expenditure in humans: Effects of dietary fat and carbohydrate. Am J Physiol 258:E347-E351, 1990

21. Acheson KJ, Schutz Y, Bessard T, et al: Nutritional influences on lipogenesis and thermogenesis after a carbohydrate meal. Am J Physiol 246:E62-E70, 1984

22. Acheson KJ, Ravussin E, Wahren J, et al: Thermic effect of glucose in man: Obligatory and facultative thermogenesis. $\mathbf{J}$ Clin Invest 74:1572-1580, 1984

23. Verboeket-van de Venne WPHG, Westerterp KR, Ten Hoor F: Substrate utilization in man: Effects of dietary fat and carbohydrate. Metabolism 43:152-156, 1994

24. Sheppard L, Kristal AR, Kushi LH: Weight loss in women participating in a randomized trial of low-fat diets. Am J Clin Nutr $54: 821-828,1991$

25. Schutz Y, Tremblay A, Weinsier RL, et al: Role of fat oxidation in the long-term stabilization of body weight in obese women. Am J Clin Nutr 55:670-674, 1992 